\title{
PEMODELAN JUMLAH TITIK PANAS DI PROVINSI KALIMANTAN TIMUR DENGAN METODE SINGULAR SPECTRUM ANALYSIS
}

\author{
Kukuh Wahyu Hidayat ${ }^{1}$, Sri Wahyuningsih ${ }^{2}$, Yuki Novia Nasution ${ }^{3}$ \\ ${ }^{1}$ Laboratorium Statistika Terapan, Fakultas MIPA, Universitas Mulawarman \\ ${ }^{2}$ Program Studi Statistika, Fakultas MIPA, Universitas Mulawarman \\ ${ }^{3}$ Program Studi Matematika, Fakultas MIPA, Universitas Mulawarman \\ e-mail: kukuhwahyu202@gmail.com
}

\begin{abstract}
Abstrak
Singular Spectrum Analysis (SSA) merupakan metode analisis runtun waktu dengan pendekatan nonparametrik, dimana metode ini tidak memerlukan beberapa asumsi. SSA cukup powerfull terutama untuk menangani data runtun waktu berpola musiman. Jumlah titik panas di Provinsi Kalimantan Timur memiliki unsur pola musiman berdasarkan beberapa penelitian yang telah dilakukan. Tujuan penelitian ini adalah menentukan model SSA terbaik yang digunakan untuk meramalkan data jumlah titik panas di Provinsi Kalimantan Timur. SSA terbagi menjadi dua tahap dasar yang saling berkaitan, yaitu tahap dekomposisi dan rekonstruksi. Pola musiman pada data dapat diketahui menggunakan analisis periodogram. Berdasarkan hasil analisis diperoleh model SSA, yaitu terdiri dari model peramalan untuk komponen tren dan model peramalan untuk komponen musiman. Tahap berikutnya dilakukan peramalan berdasarkan model yang diperoleh untuk bulan Februari 2020 hingga Januari 2021. Jumlah titik panas pada rentang bulan Februari 2020 hingga bulan Januari 2021 akan terjadi peningkatan dan penurunan titik panas secara drastis. Jumlah titik panas tertinggi akan terjadi pada bulan April tahun 2020, yaitu sebesar 1.840 titik panas.

Kata Kunci: Peramalan, Periodogram, Singular Spectrum Analysis, Titik Panas
\end{abstract}

\footnotetext{
Abstract

Singular Spectrum Analysis (SSA) is a time series analysis method with a nonparametric approach, which does not require several types of assumptions. SSA is quite powerful especially for handling seasonal patterned time series data. The number of hotspots in East Kalimantan Province has an element of seasonal patterns based on previous several studies. The purpose of this study is to determine the best SSA model used to predict data on the number of hotspots in East Kalimantan Province. The SSA is divided into two interrelated basic stages, namely the decomposition and reconstruction stages. Seasonal patterns on the data could be determined using periodogram analysis. Based on the analysis, a forecasting model for trend and seasonal component are obtained. The next stage was forecasting based on the model obtained for February 2020 until January 2021. The number of hotspots in from February 2020 to January 2021 would be increased and decreased dramatically. The highest number of hotspots would occur in April 2020, which was 1.840 hotspots.

Keywords: Forecasting, Hotspot, Periodogram, Singular Spectrum Analysis
} 


\section{PENDAHULUAN}

Peramalan adalah teknik memperkirakan atau memprediksi nilai sebuah variabel untuk beberapa waktu ke depan berdasarkan nilai yang diketahui dari variabel tersebut (Makridakis et al. 1999). Langkah penting dalam memilih model peramalan yang sesuai adalah dengan memperhatikan jenis pola data. Dalam kasus tertentu sering dijumpai data runtun waktu yang mengandung pola musiman pada proses pemodelan peramalan. Terdapat beberapa metode analisis runtun waktu yang dapat digunakan untuk menganalisis data berpola musiman diantaranya yaitu Seasonal Autoregressive Integrated Moving Average (SARIMA), Holt Winters, dan yang berkembang saat ini adalah Singular Spectrum Analysis (SSA) (Aswi and Sukarna 2006).

Menurut (Khaeri et al. 2017), SSA merupakan metode analisis runtun waktu yang cukup powerfull, terutama untuk menangani data runtun waktu berpola musiman. Hal ini karena dasar dari SSA adalah dekomposisi, dimana proses dekomposisi akan mengurangi kesalahan dalam peramalan. Metode SSA tergolong cukup fleksibel dibanding dengan model peramalan serupa. SSA terhindar dari berbagai asumsi seperti asumsi stasioneritas, normalitas residual, dan tidak memerlukan transformasi logaritma. Karena memiliki karakteristik yang cukup fleksibel, menjadikan SSA sebagai analisis dengan pendekatan nonparametrik.

Penelitian menggunakan SSA telah dilakukan oleh (Khaeri et al. 2017) untuk meramalkan jumlah penumpang kereta api. Pada penelitian tersebut diperoleh pengukuran akurasi peramalan menggunakan MAPE sebesar 5\%. Penelitian selanjutnya dilakukan oleh (Hassani 2007), yaitu membandingkan metode SSA, SARIMA, ARAR, dan Seasonal Holt-Winter menggunakan data jumlah kematian di USA sebanyak 60 data. Berdasarkan hasil penelitian tersebut diperoleh SSA memiliki kesalahan peramalan terkecil dibandingkan ketiga metode lainnya dengan MRAE sebesar 2\%. Hal ini berarti bahwa, metode SSA memberikan hasil yang relatif presisi dalam meramalkan data setiap periode waktu.

Metode SSA menjadi metode standar dalam analisis runtun waktu klimatologi, meteorologi, dan geofisika serta terbukti sangat baik digunakan pada bidang tersebut (Vautard et al. 1992). Permasalahan iklim yang dikaitkan dengan isu beberapa tahun ini adalah titik panas (hotspot). Jumlah titik panas dapat menjadi indikator deteksi dini bencana kebakaran hutan dan lahan (LAPAN 2016).

Provinsi Kalimantan Timur adalah salah satu daerah yang tidak lepas dari permasalahan titik panas. Jumlah titik panas di Provinsi Kalimantan Timur pernah tercatat ekstrim pada bulan Oktober 2015. Berdasarkan data yang dirilis oleh NASA (National Aeronautics and Space Administration), intensitas jumlah titik panas meningkat pada bulan Agustus hingga November. Salah satu upaya penting dalam antisipasi bencana kebakaran hutan dan lahan di Provinsi Kalimantan Timur adalah dengan mengetahui jumlah titik panas pada beberapa periode ke depan. Peramalan adalah langkah yang dapat dilakukan untuk mengetahui jumlah titik panas periode ke depan. Hasil peramalan dapat digunakan untuk membantu dalam mengambil keputusan terkait permasalahan titik panas.

Berdasarkan uraian tersebut, penelitian ini membahas mengenai pemodelan jumlah titik panas di Provinsi Kalimantan Timur dengan metode SSA. 


\section{METODE PENELITIAN}

Penelitian ini menggunakan data jumlah titik panas di Provinsi Kalimantan Timur Periode Januari 2010 - Januari 2020 atau sebanyak 121 data. Data penelitian diperoleh melalui website NASA. Metode yang digunakan adalah studi literatur dengan menelusuri buku, jurnal, atau sumber lainnya mengenai peramalan menggunakan SSA dan data jumlah titik panas di Provinsi Kalimantan Timur. SSA terbagi menjadi dua tahap dasar, yaitu tahap dekomposisi dan rekonstruksi. Tahap dekomposisi terbagi dalam dua langkah, yaitu embedding dan singular value decomposition. Proses rekonstruksi juga terbagi menjadi dua langkah, yaitu langkah grouping dan diagonal averaging. Berikut adalah langkah-langkah pemodelan peramalan menggunakan metode SSA:

1) Mempersiapkan data jumlah titik panas di Provinsi Kalimantan Timur periode Januari 2010 - Januari 2021.

2) Membuat grafik runtun waktu untuk mengetahui karakteristik pola data

3) Melakukan pengujian pola musiman pada data pengamatan menggunakan analisis periodogram. Menurut (Husnita et al. 2015), untuk memperoleh perioditas data dilakukan terhadap frekuensi yang berpasangan dengan titik-titik puncak garis spektrumnya. Nilai periodogram dapat dituliskan sebagai berikut (Wei 2006):

$$
I\left(\omega_{k}\right)= \begin{cases}N a_{0}^{2}, & k=0, \\ \frac{N\left(a_{k}^{2}+b_{k}^{2}\right)}{2}, & k=1, \ldots,[(N-1) / 2], \\ N a_{N / 2}^{2}, & k=\frac{N}{2}\end{cases}
$$

Dengan $a_{k}$ dan $b_{k}$ merupakan koefisien Fourier yang diperoleh melalui persamaan berikut:

$$
\begin{aligned}
& a_{k}= \begin{cases}\frac{1}{N}\left[\sum_{i=1}^{N} f_{i} \cos \left(\omega_{k} i\right)\right] & , k=0 \text { dan } k=\frac{N}{2}, \\
\frac{2}{N}\left[\sum_{i=1}^{N} f_{i} \cos \left(\omega_{k} i\right)\right] & , k=1,2, \ldots,\left[\frac{N-1}{2}\right]\end{cases} \\
& b_{k}=\frac{2}{N}\left[\sum_{i=1}^{N} f_{i} \sin \left(\omega_{k} i\right)\right] \quad, k=1,2, \ldots,\left[\frac{N-1}{2}\right] \\
& \omega_{k}=\frac{2 \pi k}{N}
\end{aligned}
$$

Tahapan selanjutnya dalam analisis menggunakan periodogram adalah pengujian hipotesis. Pengujian dapat dilakukan dengan hipotesis sebagai berikut:

$H_{0}: a_{k}=b_{k}=0$ (Tidak terdapat pola musiman)

$H_{1}: a_{k} \neq 0$ atau $b_{k} \neq 0$

(Terdapat pola musiman)

Statistik Uji

$I^{(1)}\left(\omega_{(1)}\right): \max \left\{I\left(\omega_{k}\right)\right\}$

$$
T=\frac{I^{(1)}\left(\omega_{(1)}\right)}{\sum_{k=1}^{n} I\left(\omega_{k}\right)}
$$


$I\left(\omega_{k}\right) \quad$ : Nilai periodogram pada frekuensi Fourier ke- $k$

Dengan daerah Penolakan yaitu $H_{0}$ ditolak jika $T>g_{\alpha}$. Nilai $g_{\alpha}$ terbagi atas dua jenis, yaitu $g_{\alpha}$ by exact formula dan $g_{\alpha}$ by first term only. Menurut (Darmawan et al. 2017), untuk memperoleh nilai $g_{\alpha}$ by first term only diperoleh dengan pendekatan dari $g_{\alpha}$ by exact formula yaitu sebagai berikut:

$$
\begin{gathered}
P\left(T>g_{\alpha}\right)=\alpha \\
P(T>g)=n(1-g)^{n-1}
\end{gathered}
$$

4) Embedding, yaitu mentransformasi runtun berdimensi satu dengan panjang $N$ dan tidak terdapat data missing ke dalam bentuk matriks lintasan $\mathbf{X}$ berukuran $L \times K$. Nilai $L$ adalah bilangan bulat disebut window length. Penentuan parameter window length dilakukan dengan cara trial and error yang memenuhi $2<L<N / 2$ sampai memperoleh nilai MAPE minimum. Berikut persamaan untuk membentuk matriks lintasan X (Jatmiko et al. 2017).

$$
\mathbf{X}=\left(x_{i j}\right)_{i, j=1}^{L, K}=\left(\begin{array}{cccc}
f_{1} & f_{2} & \cdots & f_{K} \\
f_{2} & f_{3} & \cdots & f_{K+1} \\
\vdots & \vdots & \ddots & \vdots \\
f_{L} & f_{L+1} & \cdots & f_{N}
\end{array}\right)
$$

5) Singular Value Decomposition (SVD) dilakukan untuk mendekomposisi nilai singular dari matriks lintasan $\mathbf{X}$ menjadi suatu penjumlahan dari matriks yang terbentuk dari eigentriple (Sari et al. 2019). Diberikan,

$$
\mathbf{S}=\mathbf{X} \mathbf{X}^{T}
$$

Misal $\lambda_{1}, \lambda_{2}, \ldots, \lambda_{L}$ merupakan nilai eigen dari matriks $\mathbf{S}$ dengan urutan menurut $\lambda_{1} \geq \ldots \geq \lambda_{L} \geq 0$ dan $\mathbf{u}_{1}, \ldots, \mathbf{u}_{L}$ merupakan vektor eigen dari masing-masing nilai eigen matriks $\mathbf{S}$. Berikutnya didefinisikan $d=\max \left\{i\right.$, sehingga $\left.\lambda_{i}>0\right\}$ sebagai rank dari matriks lintasan $\mathbf{X}$. Nilai komponen utama dinotasikan,

$$
\mathbf{v}_{i}=\mathbf{X}^{T} \mathbf{u}_{i} / \sqrt{\lambda_{i}}, i=1,2, \ldots, d
$$

maka SVD matriks lintasan $\mathbf{X}$ dapat dinyatakan melalui persamaan berikut (Jatmiko et al. 2017):

$$
\begin{aligned}
\mathbf{X} & =\mathbf{X}_{1}+\ldots+\mathbf{X}_{d} \\
& =\sqrt{\lambda_{1}} \mathbf{u}_{1} \mathbf{v}_{1}^{T}+\sqrt{\lambda_{2}} \mathbf{u}_{2} \mathbf{v}_{2}^{T}+\ldots+\sqrt{\lambda_{d}} \mathbf{u}_{d} \mathbf{v}_{d}^{T} \\
& =\sum_{i=1}^{d} \sqrt{\lambda_{i}} \mathbf{u}_{i} \mathbf{v}_{i}^{T}
\end{aligned}
$$

Matriks $\mathbf{X}$ tahap SVD ini terbentuk dari tiga elemen yang dikenal dengan eignetriple, yaitu terdiri dari nilai singular $(\sqrt{\lambda})$, vektor eigen $\left(\mathbf{u}_{i}\right)$, dan komponen utama $\left(\mathbf{v}_{i}^{T}\right)$.

6) Grouping merupakan langkah pertama dari tahap rekonstruksi. Langkah grouping dilakukan untuk memisahkan komponen musiman dengan komponen lainnya dari runtun waktu. Hal itu dilakukan dengan cara memisahkan matriks yang telah dihitung pada tahap SVD ke dalam beberapa kelompok, kemudian menjumlahkan matriks dalam setiap kelompok (Ischak et al. 2018). Menurut (Jatmiko et al. 2017), pengelompokkan akan memartisi himpunan indeks $\{1, ., d\}$ ke dalam $m$ himpunan yang saling lepas, $I_{1}, I_{2}, \ldots, I_{m}$. Misalkan $I=\left\{i_{1}, i_{2}, \ldots, i_{p}\right\}$ merupakan matriks resultan $\mathbf{X}_{I}$ dengan indeks $i_{1}, i_{2}, \ldots, i_{P}$ yang dihasilkan sesuai dengan kelompok $I$ di mana didefinisikan sebagai 
$\mathbf{X}_{I}=\mathbf{X}_{i 1}+\mathbf{X}_{i 2}+\ldots+\mathbf{X}_{i p}$. Matriks $\mathbf{X}_{I}$ disesuaikan dengan kelompok $I_{1}, I_{2}, \ldots, I_{m}$ dan diekspansi dengan Persamaan 10 menjadi :

$$
\mathbf{X}=\mathbf{X}_{I 1}+\mathbf{X}_{I 2}+\ldots+\mathbf{X}_{I m}
$$

7) Matriks w-correlation digunakan untuk menganalisis keterpisahan kelompok yang terbentuk. Terdapat dua jenis keterpisahan yaitu keterpisahan kuat dan lemah. Berikut merupakan persamaan untuk menentukan besarnya korelasi terboboti atau $w$-correlation (Hassani and Mahmoudvand 2018).

$$
\rho^{(w)}\left(F^{(1)}, F^{(2)}\right)=\frac{\left(F^{(1)}, F^{(2)}\right)_{w}}{\sqrt{\left(F^{(1)}, F^{(1)}\right)_{w}} \sqrt{\left(F^{(2)}, F^{(2)}\right)_{w}}},
$$

di mana,

$$
\left(F^{(1)}, F^{(2)}\right)_{w}=\sum_{i=1}^{N} w_{i} f_{i}^{(1)} f_{i}^{(2)},
$$

dengan bobot dihitung sebagai berikut:

$$
w_{i}= \begin{cases}i & , 1 \leq i<L^{*}, \\ L^{*} & , L^{*} \leq i \leq K^{*}, \\ N-i+1 & , K^{*}<i \leq N .\end{cases}
$$

Dua runtun $F^{(1)}$ dan $F^{(2)}$ dapat dipisahkan jika $\rho^{(w)}\left(F^{(1)}, F^{(2)}\right) \square 0$ (Golyandina and Zhigljavsky 2013).

8) Diagonal Averaging merupakan langkah terakhir dari proses rekonstruksi. Langkah diagonal averaging dilakukan dengan mentransformasi setiap matriks $\mathbf{X}_{I j}$ pada tahap pengelompokkan menjadi suatu runtun baru dengan panjang $N$. Diberikan $\mathbf{Y}$ sebuah matriks berukuran $L \times K$ dengan elemen $y_{i j}$, dimana $1 \leq i \leq L$ dan $1 \leq j \leq K$. Diagonal averaging akan mentransformasi matriks $\mathbf{Y}$ ke dalam bentuk runtun kembali dengan menggunakan persamaan berikut:

$$
g_{k}= \begin{cases}\frac{1}{k} \sum_{m=1}^{k} y_{m, k-m+1}^{*} & 1 \leq k<L^{*}, \\ \frac{1}{L^{*}} \sum_{m=1}^{L^{*}} y_{m, k-m+1}^{*} & L^{*} \leq k \leq K^{*}, \\ \frac{1}{N-k+1} \sum_{m=k-K^{*}+1}^{N-K^{*}+1} y_{m, k-m+1}^{*} & K^{*}<k \leq N .\end{cases}
$$

$L^{*}=\min (L, K)$ dan $K^{*}=\max (L, K)$ dengan $y_{i j}^{*}=y_{i j}$ jika $L<K$ dan $y_{i j}^{*}=y_{j i}$ jika $L>K$

(Khaeri et al. 2018). Persamaan 15 tersebut akan diaplikasikan pada matriks resultan $\mathbf{X}_{\text {Im }}$ di mana membentuk runtun $\tilde{\mathbf{F}}^{(k)}=\tilde{f}_{1}^{(k)}, \tilde{f}_{2}^{(k)}, \ldots, \tilde{f}_{N}^{(k)}$, oleh karena itu runtun awal akan didekomposisi menjadi jumlah dari $m$ runtun yang direkonstruksi ditunjukkan pada persamaan berikut (Jatmiko et al. 2017):

$$
\tilde{f}_{i}=\sum_{k=1}^{m} \tilde{f}_{i}^{(k)} \quad, i=1,2, \ldots, N
$$

9) Recurrent Forecasting ( $R$-Forecasting) adalah salah satu metode peramalan dalam SSA. Peramalan R-Forecasting berkaitan dengan penaksiran Linier Recurrent Formula (LRF). Misalkan $\mathbf{u}_{i}^{\nabla}$ adalah vektor komponen pertama $L-1$ dari vektor eigen $\mathbf{u}_{i}$ dan 
$\pi_{i}$ adalah komponen terakhir dari $\mathbf{u}_{i}(i=1, \ldots, l)$ dengan $v^{2}=\sum_{i=1}^{l} \pi_{i}^{2}$, maka $R$ dapat didefinisikan sebagai vektor yang terdiri dari koefisien LRF suatu komponen (Hassani and Mahmoudvand, 2018).

$$
R=\left(a_{L-1}, \ldots, a_{1}\right)=\frac{1}{1-v^{2}} \sum_{i=1}^{l} \pi_{i} \mathbf{u}_{i}^{\nabla}
$$

Data runtun waktu yang digunakan pada $R$-forecasting adalah data runtun hasil rekonstruksi yang diperoleh melalui tahap diagonal averaging. Hasil peramalan diperoleh berdasarkan persamaan berikut:

$$
g_{i}= \begin{cases}\tilde{f}_{i} & , i=1, \ldots, N \\ \sum_{j=1}^{L-1} a_{j} g_{i-j} & , i=N+1, \ldots, N+M\end{cases}
$$

di mana $g_{N+1}, g_{N+2}, \ldots, g_{N+M}$ adalah hasil peramalan menggunakan SSA (Jatmiko et al. 2017).

10) Langkah terakhir dari proses peramalan SSA adalah menghitung akurasi peramalan. Semakin kecil tingkat kesalahan prediksi, maka semakin baik suatu nilai ramalan atau prediksi. Untuk mengetahui akurasi peramalan dapat dilakukan dengan melihat nilai rata-rata persentase kesalahan yang telah diabsolutkan yang dikenal dengan mean absolute percentage error (MAPE). Nilai MAPE dihitung melalui persamaan berikut:

$$
\text { MAPE }=\frac{1}{N} \sum_{i=1}^{N}\left|\frac{f_{i}-g_{i}}{f_{i}}\right| \times 100 \%
$$

di mana $N$ adalah banyak data runtun waktu, $f_{i}$ merupakan nilai pengamatan dan $g_{i}$ adalah hasil peramalan (Sungkawa and Megasari 2011).

\section{HASIL DAN PEMBAHASAN}

\subsection{Data Penelitian}

Penelitian ini menggunakan data jumlah titik panas di Provinsi Kalimantan Timur. Data jumlah titik panas merupakan data sekunder yang yang diperoleh dari website National Aeronautics and Space Administration (NASA). Data jumlah titik panas merupakan data runtun waktu hasil akumulasi per bulan. Data yang dianalisis dari bulan Januari 2010 hingga bulan Januari 2020 atau sebanyak 121 data runtun waktu. Langkah awal sebelum melakukan peramalan adalah mengetahui karakteristik pola data. Karakteristik pola data jumlah titik panas dapat dilihat melalui grafik runtun waktu. Grafik runtun waktu jumlah titik panas di Provinsi Kalimantan Timur periode Januari 2010 hingga Januari 2020 dapat dilihat melalui Gambar 1.

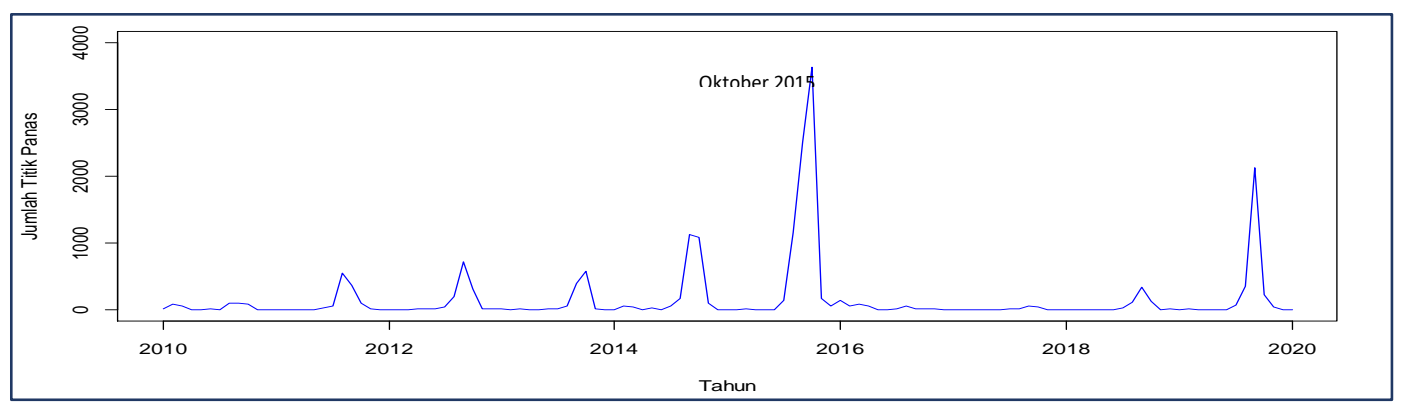

Gambar 1. Grafik runtun waktu jumlah titik panas di Provinsi Kalimantan Timur 
Gambar 1 menunjukkan grafik runtun waktu jumlah titik panas di Provinsi Kalimantan Timur cenderung membentuk pola musiman. Pola musiman dapat dilihat dari adanya unsur keperiodikan di beberapa periode waktu. Jumlah titik panas tertinggi terjadi pada bulan Oktober 2015 yaitu mendekati 4000 titik panas. Jumlah terendah terjadi di beberapa periode waktu yaitu mendekati 0 titik panas.

\subsection{Analisis Periodogram}

Nilai periodogram yang diperoleh pada Persamaan (1) dapat divisualisasikan dalam bentuk grafik untuk mengetahui perioditas data. Periodogram data jumlah titik panas di Provinsi Kalimantan Timur periode Januari 2010 sampai bulan Januari 2020 ditunjukkan melalui Gambar 2.

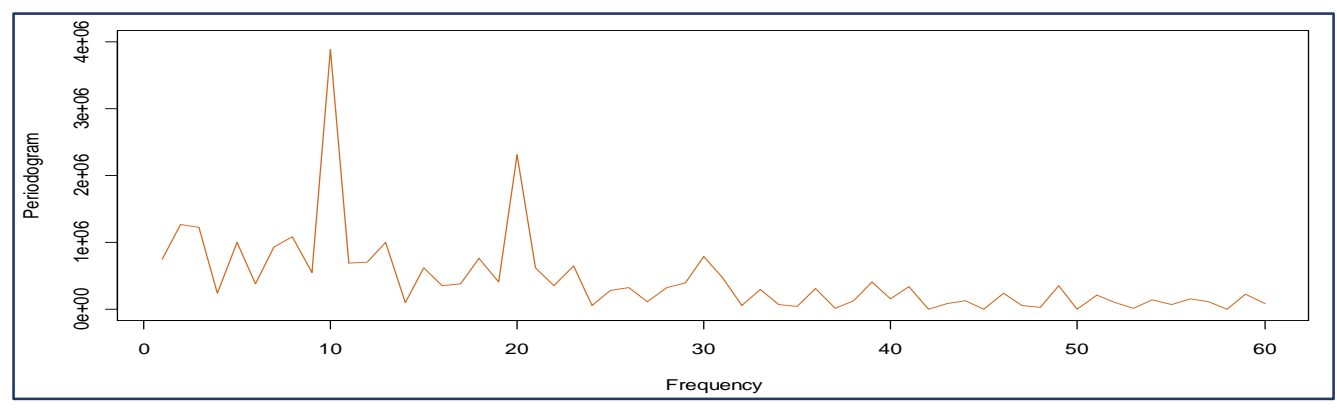

Gambar 2. Periodogram data jumlah titik panas di Provinsi Kalimantan Timur

Periodogram pada Gambar 2 memperlihatkan bahwa terdapat titik-titik puncak pada periodogram dan hampir terdapat kestabilan titik periodogram dalam setiap frekuensi. Dapat disimpulkan bahwa ada keperiodikan data pada periode tertentu. Dengan kata lain data jumlah titik panas di Provinsi Kalimantan Timur merupakan data musiman. Analisis secara grafik tentu masih bersifat subjektif, oleh karena itu untuk mendukung hasil analisis secara grafis dilakukan pengujian hipotesis. Berikut hasil pengujian hipotesis analisis periodogram.

Hipotesis

$$
\begin{array}{ll}
H_{0}: a_{k}=b_{k}=0 \quad, k=1,2, \ldots, 60 & \text { (Tidak terdapat pola musiman pada data) } \\
H_{1}: a_{k} \neq 0 \text { atau } b_{k} \neq 0, k=1,2, \ldots, 60 \quad \text { (Terdapat pola musiman pada data) }
\end{array}
$$

Statistik Uji

$$
T=\frac{I^{(1)}\left(\omega_{(1)}\right)}{\sum_{k=1}^{60} I\left(\omega_{k}\right)}=\frac{3.888 .110}{27.004 .597}=0,14398
$$

Keputusan

Karena $T>g_{0,05}$, di mana $g_{0,05}=0,11323$ yang diperoleh pada Persamaan (7) dengan taraf signifikansi sebesar 5\% maka diputuskan $H_{0}$ ditolak

Berdasarkan analisis secara grafis periodogram dan dengan pengujian hipotesis diperoleh kesimpulan bahwa data jumlah titik panas di Provinsi Kalimantan Timur periode Januari 2010 sampai Januari 2020 merupakan data berpola musiman.

\subsection{Dekomposisi}

Langkah pertama dalam tahap dekomposisi adalah proses embedding. Pada penelitian ini jumlah data sebanyak 121 data runtun waktu sehingga nilai $L$ yang digunakan berkisar mulai $L=3$ hingga $L=60$. Melalui proses trial and error diperoleh $L=20$ merupakan MAPE 
terkecil dibandingkan $L$ lainnya. Berdasarkan nilai $L=20$ maka dimensi $K=102$. Dengan demikian matriks lintasan $\mathbf{X}$ dapat disusun sebagai berikut:

$$
\mathbf{X}=\left(x_{i j}\right)_{i, j=1}^{20,102}=\left(\begin{array}{cccc}
11 & 85 & \cdots & 2 \\
85 & 58 & \cdots & 28 \\
\vdots & \vdots & \ddots & \vdots \\
549 & 363 & \cdots & 4
\end{array}\right)
$$

Setelah memperoleh matriks lintasan $\mathbf{X}$ langkah berikutnya adalah mendekomposisi nilai singular (SVD) matriks S pada Persamaan (2). Proses SVD matrik S meghasilkan 20 eigentriple di mana terdiri dari nilai eigen, vektor eigen, dan komponen utama.

Tabel 1. Nilai Singular

\begin{tabular}{ccc}
\hline & $\lambda_{i}$ & $\sqrt{\lambda_{i}}$ \\
\hline 1 & 100.404 .108 & $10.020,185$ \\
2 & 72.643 .101 & $8.523,092$ \\
3 & 64.493 .153 & $8.030,763$ \\
$\vdots$ & $\vdots$ & $\vdots$ \\
20 & 3.639 .363 & $1.907,711$
\end{tabular}

Tabel 2. Vektor Eigen

\begin{tabular}{cccc}
$\mathbf{u}_{1}$ & $\mathbf{u}_{2}$ & $\cdots$ & $\mathbf{u}_{20}$ \\
\hline$-0,146$ & $-0,243$ & $\cdots$ & $-0,137$ \\
$-0,195$ & $-0,297$ & $\cdots$ & 0,323 \\
$-0,234$ & $-0,255$ & $\cdots$ & $-0,419$ \\
$\vdots$ & $\vdots$ & $\vdots$ & $\vdots$ \\
$-0,191$ & 0,274 & $\cdots$ & 0,032
\end{tabular}

Tabel 3. Komponen Utama

\begin{tabular}{cccc}
$\mathbf{v}_{1}$ & $\mathbf{v}_{2}$ & $\ldots$ & $\mathbf{v}_{20}$ \\
\hline$-0,021$ & 0,021 & $\ldots$ & 0,005 \\
$-0,033$ & 0,038 & $\ldots$ & $-0,006$ \\
$-0,039$ & 0,039 & $\ldots$ & 0,007 \\
$\vdots$ & $\vdots$ & $\vdots$ & $\vdots$ \\
$-0,097$ & $-0,055$ & $\ldots$ & $-0,056$
\end{tabular}

Eigentriple tersebut akan digunakan pada tahap berikutnya, yaitu sebagai dasar pengelompokkan (grouping).

\subsection{Rekonstruksi}

Pada tahap awal rekonstruksi adalah melakukan pengelompokkan eigentriple yang telah diperoleh pada tahap SVD. Eigentriple yang memiliki karakteristik hampir sama akan dikelompokkan ke dalam satu kelompok atau komponen. Pengelompokkan dilakukan melalui analisis secara grafis, yaitu grafik nilai singular, grafik vektor eigen, dan matriks $w$ correlation.

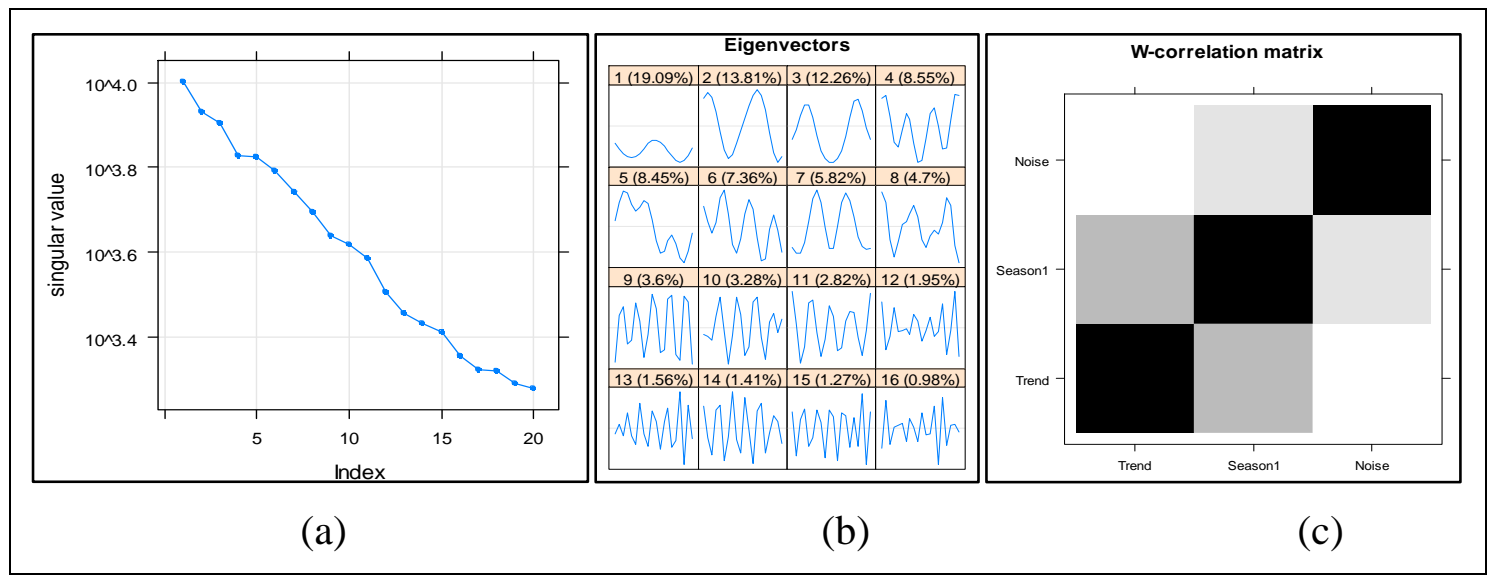

Gambar 3. (a) grafik nilai singular (b) grafik vektor eigen (c) matriks w-correlation

Berdasarkan Gambar 3 (a) nilai singular menurun secara lambat pada singular 17 sampai 20. Nilai singular yang menurun secara lambat dapat diidentifikasi sebagai unsur noise. Oleh karena itu, eigentriple 17 sampai eigentriple 20 dikelompokkan sebagai unsur noise. Berikutnya pengelompokkan komponen tren dan musiman yang dapat dianalisis melalui grafik vektor eigen. Pada Gambar 3 (b) kurva vektor eigen 1 dan 5 memuat unsur tren. Selain itu, nilai persentase pada vektor eigen 1 sebesar 19,09\% terlihat berbeda jauh dengan nilai 
persentase vektor eigen lainnya. Dengan demikian, eigentriple 1 dan eigentriple 5 dapat dikelompokkan ke dalam komponen tren. Selanjutnya kurva vektor eigen 2 dan kurva vektor eigen 3 memiliki kesamaan pola, yaitu cenderung membentuk pola musiman. Demikian juga dengan eigentriple 4 hingga eigentriple 15 yang terlihat memiliki pola musiman melalui kurva vektor eigen. Oleh karena itu, eigentriple 2 hingga eigentriple 15 dikelompokkan ke dalam kelompok musiman. Sisa eigentriple yang tidak dikelompokan ke dalam kelompok tren dan musiman dari 16 eigentriple sebelumnya akan dikelompokan kembali ke dalam kelompok noise. Berdasarkan matriks w-correlation pada Gambar 3 (c) menunjukkan bahwa gradasi warna antara satu kelompok dengan kelompok yang lainnya tidak terlihat pekat. Artinya keterpisahan kelompok yang terbentuk pada proses grouping telah dikatakan berhasil.

Langkah terakhir dari proses rekonstruksi adalah dengan melakukan diagonal averaging. Hasil diagonal averaging berdasarkan Persamaan (16) dan Persamaan (17) dapat ditunjukkan pada Tabel 4.

Tabel 4. Hasil Diagonal Averaging

\begin{tabular}{|c|c|c|c|}
\hline \multirow{2}{*}{$\begin{array}{l}\text { Waktu } \\
\text { ke- }\end{array}$} & \multicolumn{2}{|c|}{ Rekonstruksi } & \multirow{2}{*}{$\begin{array}{c}\text { Diagonal } \\
\text { Averaging }\end{array}$} \\
\hline & Tren & Musiman & \\
\hline 1 & 33,781 & $-21,410$ & 12,371 \\
\hline 2 & 46,131 & 36,266 & 82,397 \\
\hline 3 & 48,348 & 19,061 & 67,409 \\
\hline 4 & 42,765 & $-61,999$ & $-19,234$ \\
\hline 5 & 37,827 & $-2,3195$ & 35,507 \\
\hline$\vdots$ & : & $\vdots$ & \\
\hline 121 & 204,633 & $-159,626$ & 45,006 \\
\hline
\end{tabular}

\subsection{Peramalan}

Berikutnya melakukan pemodelan untuk peramalan 12 periode selanjutnya, yaitu bulan Februari 2020 hingga Januari 2020. Pemodelan dilakukan dengan metode R-Forecasting di mana berkaitan dengan penaksiran koefisien LRF. Koefisien LRF diperoleh melalui Persamaan (18) untuk masing-masing komponen. Koefisien LRF tersebut digunakan untuk membentuk model peramalan $R$-Forecasting. Berdasarkan Persamaan (19), berikut adalah model peramalan yang digunakan untuk komponen tren.

$$
g_{i}=\left(0,06703 g_{i-1}\right)+\left(0,08230 g_{i-2}\right)+\ldots .+\left(0,02486 g_{i-19}\right)
$$

Dengan cara yang sama berikut adalah model peramalan untuk komponen musiman.

$$
g_{i}=\left(-0,75931 g_{i-1}\right)+\left(-1,57570 g_{i-2}\right)+\ldots .+\left(-0,71617 g_{i-19}\right)
$$

Tahap terakhir adalah melakukan peramalan untuk masing-masing komponen dan menjumlahkan hasil peramalan untuk setiap periode. Hasil peramalan dapat ditunjukkan melalui Gambar 4. 


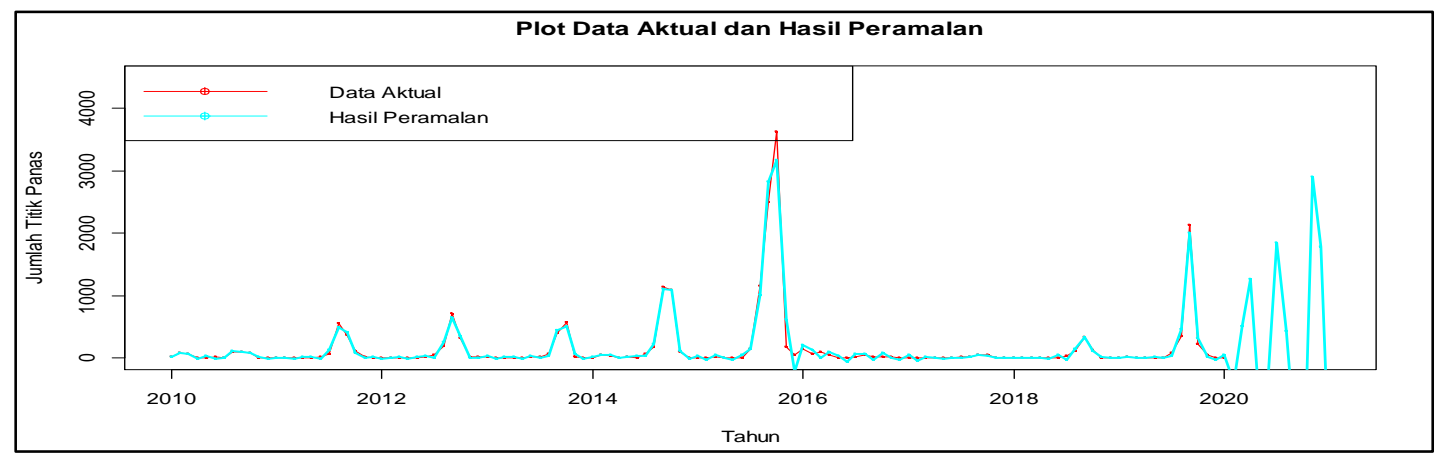

Gambar 4. Grafik Hasil Peramalan Jumlah Titik Panas Di Provinsi Kalimantan Timur

Secara visual Gambar 4 menunjukkan bahwa pola grafik hasil peramalan jumlah titik panas di Provinsi Kalimantan Timur menggunakan $R$-Forecasting pada SSA menyerupai pola pada data aktual. Hasil peramalan jumlah titik panas bulan Februari 2020 hingga bulan Januari 2021 mengalami peningkatan dan penurunan secara drastis. Secara rinci hasil peramalan dapat dilihat pada Tabel 5.

Tabel 5. Hasil Peramalan Jumlah Titik Panas Di Provinsi Kalimantan Timur

\begin{tabular}{lrrr}
\hline \multirow{2}{*}{ Waktu } & \multicolumn{2}{c}{ Peramalan } & Jumlah Titik \\
\cline { 2 - 3 } & Komponen Tren & Komponen Musiman & Panas \\
\hline Februari 2020 & 176,475 & $-564,088$ & -388 \\
Maret 2020 & 173,405 & 331,143 & 504 \\
April 2020 & 170,144 & $1.091,233$ & 1.261 \\
Mei 2020 & 166,803 & $-1.082,062$ & -915 \\
Juni 2020 & 163,008 & $-413,096$ & -250 \\
Juli 2020 & 159,213 & $1.681,252$ & 1.840 \\
Agustus 2020 & 156,986 & 270,383 & 427 \\
September 2020 & 157,674 & $-1.387,347$ & -1.230 \\
Oktober 2020 & 160,956 & $-2.403,826$ & -2.243 \\
November 2020 & 164,900 & $2.737,286$ & -2.902 \\
Desember 2020 & 167,282 & $1.615,507$ & 1.783 \\
Januari 2021 & 166,907 & $-2.589,447$ & -2.423 \\
\hline
\end{tabular}

Berdasarkan hasil peramalan pada Tabel 4.7 dapat diketahui bahwa jumlah titik panas pada awal tahun 2020, yaitu bulan Maret 2020 sebesar 504 titik panas. Periode berikutnya, yaitu bulan April 2020 mengalami kenaikan jumlah titik panas menjadi 1.261 titik. Terjadi peningkatan jumlah titik panas yang cukup ekstrim yaitu sebanyak 1.840 titik panas pada bulan Juli 2020. Hasil peramalan menunjukkan terdapat peramalan bernilai negatif yang terjadi di beberapa periode. Nilai negatif tersebut dapat terjadi kemungkinan terdapat beberapa lonjakan data yang cukup ekstrim (outlier) pada data jumlah titik panas periode Januari 2010 hingga Januari 2020.

\section{KESIMPULAN}

Model peramalan SSA menggunakan $R$-forecasting untuk data jumlah titik panas Kalimantan Timur periode Januari 2010 sampai Januari 2020 terbagi menjadi dua model, yaitu model peramalan untuk komponen tren dan model peramalan untuk komponen 
musiman. Hasil peramalan jumlah titik panas bulan Februari 2020 hingga bulan Januari 2021 mengalami peningkatan dan penurunan secara drastis. Terjadi peningkatan jumlah titik panas yang cukup ekstrim yaitu sebanyak 1.840 titik panas pada bulan Juli 2020.

\section{DAFTAR PUSTAKA}

Aswi and Sukarna. (2006), Analisis Runtun Waktu Aplikasi dan Teori, Makassar: Andira Publisher.

Darmawan, G., Handoko, B., and Zulhanif. (2017), "Identifikasi Perubahan Pola Curah Hujan Melalui Periodogram Standar," JMP, 9, 103-112.

Golyandina, N., and Zhigljavsjy, A. (2013), Singular Spectrum Analysis for Time Series, New York: Springer.

Hassani, H. (2007), "Singular Spectrum Analysis: Methodoogy and Comparison," Journal of Data Science, 5, 239-257.

Hassani, H., and Mahmoudvand, R. (2018), Singular Spectrum Analysis With R, Iran: Palgrave Advance Texts in Econometric.

Husnita, F., Wahyuningsih, S., and Nohe, D. A. (2015), "Analisis Spektral dan Model ARIMA Untuk Peramalan Jumlah Wisatawan di Dunia Fantasi Taman Impian Jaya Ancol," Jurnal Eksponensial, 6, 21-29.

Ischak, R., Asrof, A., and Darmawan, G. (2018), "Peramalan Rata-Rata Harga Beras di Tingkat Penggilingan Menggunakan Model Singular Spectrum Analysis (SSA)," in Prosiding Seminar Nasional Matematika dan Pendidikan Matematika, Universitas Muhammadiyah Purworejo, pp. 57-64.

Jatmiko, Y. A., Rahayu, R. L, and Darmawan, G, "Perbandingan Keakuratan Hasil Peramalan Produksi Bawang Merah Metode Holt-Winters dengan Singular Spectrum Analysis (SSA)," Jurnal Matematika (MANTIK), 3, 13-22.

Khaeri, H., Yulian, E., and Darmawan, G. (2017), "Penerapan Metode Singular Spectrum Analysis (SSA) Pada Peramalan Jumlah Penumpang Kereta Api di Indonesia Tahun 2017," Jurnal Euclid, 5, 8-20.

LAPAN. (2016), Panduan Teknis (V.01) Informasi Titik Panas (Hotspot) Kebakaran Hutan/Lahan, Jakarta: Pusat Pemanfaatan Penginderaan Jauh Deputi Bidang Penginderaan Jauh-LAPAN.

Makridakis, S., Wheelwright, S. C., and McGee, V. E. (1999), Metode dan Aplikasi Peramalan, Edisi 2, Jakarta: Erlangga.

Sari, M. A. N., Sumarjaya, I. W., and Susilawati, M. (2019), "Peramalan Jumlah Kunjungan Wisatawan Mancanegara ke Bali Menggunakan Metode Singular Spectrum Analysis," EJurnal Matematika, 8, 303-308.

Sungkawa, I., and Megasari, R. T. (2011), "Penerapan Ukuran Ketepatan Nilai Ramalan Data Runtun Waktu Dalam Seleksi Model Peramalan Volume Penjualan PT. Satriamandiri Citramulia," ComTech, 2, 636-645.

Vautard, R., Yiou, P., and Ghil, M. (1992), "Singular-spectrum analysis: A toolkit for short, noisy chaotic signals," Physica. D, 58, 95-126.

Wei, W. S. (2006), Time Series Analysis: Univariate and Multivariate Methods (2nd Edition), New York: Addison Wesley Publishing Company. 